\title{
Antarctic fish growth: profile of Trematomus newnesi
}

\author{
R. L. Radtke ${ }^{1}$, T. E. Targett ${ }^{2}$, A. Kellermann ${ }^{3}$, J. L. Bell ${ }^{4}$, K. T. Hill ${ }^{4}$ \\ ${ }^{1}$ Oceanic Biology, Hawaii Institute of Geophysics, University of Hawaii, Honolulu, Hawaii 96822, USA \\ ${ }^{2}$ University of Delaware, College of Marine Studies, Lewes, Delaware 19958, USA \\ ${ }^{3}$ Alfred Wegener Institute for Polar Research, Columbus Center, D-2850 Bremerhaven, Federal Republic of Germany \\ ${ }^{4}$ University of Hawaii, Department of Zoology, 2538 The Mall, Honolulu, Hawaii 96822, USA
}

\begin{abstract}
Life history stages of the Antarctic Peninsula population of the notothenioid Trematomus newnesi were examined to gain insights into life history patterns and to understand population processes of ecologically important polar fishes. Sampling yielded 156 larvae and post-larvae and 236 juveniles and adults. Otoliths from these samples were examined for size, morphology and microstructure. External and internal examination of otoliths from $T$. newnesi by scanning electron microscopy (SEM) revealed species-specific external shape, and internal rhythmic patterns. No annual increments could be identified in $I$ newnesi otoliths, but apparent daily increments and hatching marks were present. Tetracycline marking of live fish indicated that increments were formed daily, despite extreme variation in photoperiod. Hatching season was estimated by back calculation of otolith increments to be from September to November, with recruitment to adulthood at age 1 yr. Growth data conformed well to the Gompertz growth equation for juveniles and to the von Bertalanffy equation for adults. Fish grew slowly with the largest fish attaining 7 yr A multivariate mathematical model, relating age to otolith morphometrics and fish size, demonstrated that age could be reliably determined from body and otolith measurements. This correlation makes it possible to age much larger samples of fish. The life-history profile of $T$ newnesi may be typical of many polar fishes. Otolith methodology appears relevant for obtaining ages for large samples and for studying life history and population dynamics of polar fishes.
\end{abstract}

\section{INTRODUCTION}

The evolutionary radiation and ecological adaptations of the Antarctic fish fauna of the sub-order Notothenoider have taken place with essentially little exchange with fish fauna outside the Antarctic region (DeWitt 1971). Notothenioids lack swim bladders and are mostly benthic, but a number of species have evolved to occupy the mid-waters of the Antarctic oceans by adapting a pelagic lifestyle which enables them to exploit an abundant zooplankton food supply. In the present study, we investigated life history aspects of Trematomus newnesi Boulenger, a circumantarctic fish mainly confined to coastal, shallow waters to bottom depths of about $160 \mathrm{~m}$ (DeWitt \& Hureau 1979, Targett 1981, Daniels \& Lipps 1982).

Ageing of larval, juvenile and adult fish is essential to determine recruitment, growth and mortality rates. Otoliths are considered one of the best structures for age determination (Six \& Horton 1977), and they have been used to study polar fishes. Olsen (1955) inter- preted otolith annuli from the ice fishes Chaenocephalus aceratus and Champsocephalus gunnari and obtained one of the first age estimates of Antarctic fish. He discovered that the otoliths from these fishes were small and very difficult to analyze. More recently otoliths have been utilized extensively to age Antarctic fishes (North et al. 1980). Burchett et al. (1984) visualized annuli in Dissostichus mawsoni to estimate growth, while North et al. (1984) demonstrated the species differences among Antarctic fish otoliths and showed that many otoliths have rhythmic patterns. Daniels (1983) was one of the first investigators to utilize otoliths to determine population dynamics and demographic characteristics of Harpagifer bispinis.

It is now possible to determine the age of fish through the utilization of daily increments in otoliths. Daily growth rhythms were first postulated to be visible in fish otoliths by Pannella $(1971,1974)$. Since this discovery, many studies have dealt with daily increments in the otoliths of wild and captive fishes (Campana \& Neilson 1985, Jones 1986). Brothers (1982) concluded 
that daily increments are present, at least during the early life-history stages in all bony fishes. Microincrements are, therefore, particularly useful for the ageing of larval fishes. Microstructural growth increments, described in Antarctic fish otoliths (Townsend 1980), are most likely daily increments as have been found in many fish species (see review by Campana \& Neilson 1985). These microincrements were used to age Nototheniops larseni (Radtke \& Targett 1984) and Nototheniops nudifrons (Hourigan \& Radtke 1989), and are the foundation of the present research. Microincrements generally form in response to changes in calcium deposition during the daily periods of light and dark (Tanaka et al. 1981). This suggests that special problems may exist in the analysis of rings deposited during short photoperiods in Antarctic winters, and experimental validation of the daily nature of microincrement formation is necessary. Increment deposition rate in $T$. newnesi was verified through the introduction of dated marks onto the otoliths.

As a widespread and abundant species, Trematomus newnesi may be important both as a competitor and prey species, and may play a major role in the trophic structure of the Antarctic marine ecosystem. In the present study, the age and growth of $T$. newnesi were analyzed structurally through the examination of microincrements in sagitta. Otolith morphometrics were related to age, which allowed ageing of a large sample of fish. Through the analysis of microincrements on the sagittae we determined larval recruitment period and age at recruitment into the adult population, and we estimated mortality rates.

\section{METHODS AND MATERIALS}

Samples of Trematomus newnesi were collected during cruises in austral summers and one winter in the Antarctic Peninsula area (Fig. 1). Early stages were collected during several Antarctic Expeditions of the Federal Republic of Germany (FRG) using an RMT $1+8$ (rectangular, mid-water trawl) equipped with 320/4500 um meshes. Fish were collected in spring (November 15 to December 12, 1977; October 25 to November 16 , 1983; November 21 to December 4, 1984; see Fig. 1), and throughout summer and fall of the $1977 / 78$ season Further samples were obtained during other expeditions of the FRG (Kellermann 1986a). Standard oblique hauls were made from 140 or $200 \mathrm{~m}$ to the surface, as described by Kellermann (1986b). Larvae, juveniles, and adults used for ageing were sorted and stored either frozen or in $96 \%$ ethanol. Upon capture, fish were measured to the nearest $\mathrm{mm}$ (total and standard length), weighed to the nearest $0.001 \mathrm{~g}$, and their sagittal otoliths were removed, air-dried, and stored.
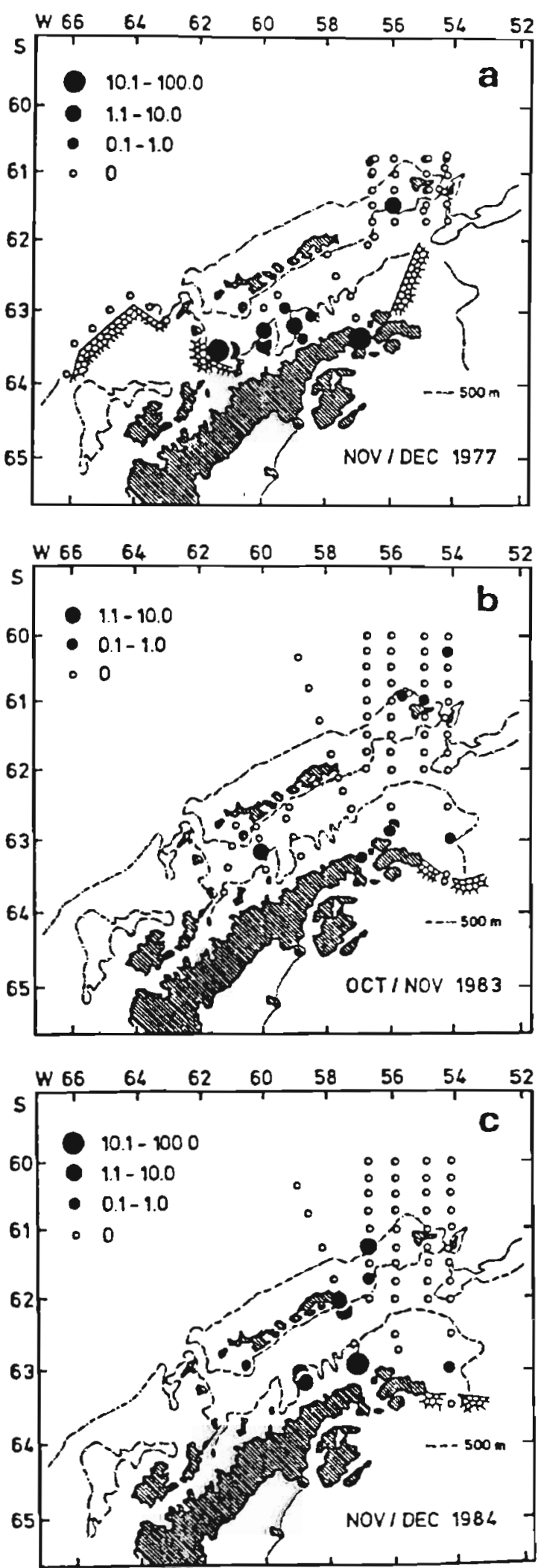

Fig. 1. Area of the Antarctic Peninsula sampled for life history stages of Trematomus newnesi and quantitative distribution of larvae (numbers per $10^{3} \mathrm{rm}^{3}$ ) in spring (a) 1977, (b) 1983, and (c) 1984. Abundance estimates refer to RMT 1 catches only (see Kellermann 1986a) 
T. newnesi juveniles and adults were captured in otter trawls in 54 to $110 \mathrm{~m}$ depths off Low Island $\left(63^{\circ} 24^{\prime} \mathrm{S}\right.$ to $63^{\circ} 27^{\prime} \mathrm{S} ; 62^{\circ} 07^{\prime} \mathrm{W}$ to $62^{\circ} 17^{\prime} \mathrm{W}$ ) during the early austral spring of 1985. T newnesi juveniles and adults were taken at depths of less than $50 \mathrm{~m}$.

Fish used for otolith validation studies were transported live to Palmer Station and placed in tanks with flow-through seawater. In addition to these fish, 30 fish were collected near Palmer Station in Arthur Harbor $\left(64^{\circ} 46^{\prime} \mathrm{S} ; 64^{\circ} 04^{\prime} \mathrm{W}\right)$ by hook and line for marking and rearing experiments. In order to test the daily nature of otolith increments, these fish were injected with tetracycline and kept in $500 \mathrm{l}$ flow-through tanks, at ambient temperature and natural photoperiod. Validation of daily increments was accomplished through a series of holding experiments where individual fish were injected intramuscularly with $25 \mathrm{mg}(\mathrm{kg}$ body $w t)^{-1}$ tetracycline hydrochloride. Fish in tanks were fed ad libitum with krill every $2 \mathrm{~d}$. Fish were kept alive for a maximum of $153 \mathrm{~d}$ after injection, from April to October, at which time they were sacrificed, weighed and measured. Otoliths of these fish were removed, cleaned and stored in vials.

Tetracycline is incorporated into the otolith and marks the time of injection. When viewed under a compound microscope at filtered reflected wavelengths of 700 to $800 \mathrm{~nm}$, tetracycline fluoresces and appears as a fluorescent band inside the otolith. The microincrements were counted beyond that point.

Left sagittae from fish injected with tetracycline were embedded in epoxy casing resin and serially sectioned using a low speed saw. The sections were polished, placed in non-fluorescent immersion oil and examined under reflected ultraviolet light, through a compound microscope. The number of microincrements from the reference point of the fluorescent mark to the margin of the otolith was counted. This number was then compared to the number of days between injection and the day the fish was sacrificed.

Age was determined for 72 larvae, juveniles, and adults. Before polishing, otoliths were examined with a light dissection microscope to determine the best plane to section for enumeration of microstructural growth increments. Otoliths were prepared for scanning electron microscopy (SEM) as described in Radtke \& Targett (1984). Left sagittae were attached to SEM viewing stubs with epoxy, carefully ground down to the central area by hand using a fine sharpening stone and then polished with $0.3 \mu \mathrm{m}$ alumina paste. The polished sections were etched for 1 to 20 min with $6 \%$ ethylene diamine tetraacetate (EDTA) with $\mathrm{pH}$ adjusted to 8 by $\mathrm{NaOH}$ to enhance incremental patterns in the surface relief. After etching, the sections were gently washed with water, dried, coated with gold, and viewed by SEM at various magnifications (50 to $10000 \times$ ).
Otoliths were examined for microincrements. A microincrement was defined as an unbroken incremental zone with discontinuous zones as boundaries (Radtke \& Dean 1982). It was not possible to view all microincrements from the edge to the core at one time. It was discovered that different areas of the sagittae were made visible by different etching times. Sequential etching made it feasible to enumerate all increments. Individual sections were etched for different periods of time, with 15 to $20 \mathrm{~min}$ etching times showing the inner increments most clearly, and shorter etching times revealing the outer increments. Landmark scratches were placed on each section in order to follow increments uncovered by different etching periods. Thus each section was etched in steps of 1 min and viewed with the SEM after each etching to follow the progression of the smallest increments found. Microstructural increment counts were then made for each otolith.

Based on the finding that 1 increment represented 1 d growth, a theoretical growth curve was calculated using the von Bertalanffy equation (Ricker 1975):

$$
\mathrm{L}_{\mathrm{t}}=\mathrm{L}_{\varkappa}\left(1-\mathrm{e}^{-k\left(t-\mathrm{t}_{0}\right)}\right)
$$

where: $\mathrm{L}_{x}=$ theoretical maximum length; $\mathrm{L}_{\mathrm{t}}=$ length at time $t ; k=$ constant indicating the rate of change in length (the Brody growth coefficient); and $t_{0}=$ time the fish would have been $0 \mathrm{~mm}$ (time of hatching) had its growth been consistent with that described by the equation.

The constants $L, k$ and $t_{0}$ were computed using the methods described by Ricker (1975).

Growth of the larvae was described through utilization of the Gompertz growth equation to relate age to size at time of capture. We used the log-transformed version of the Gompertz growth equation in order to stabilize the variance of fish length among ages. The equation is:

$$
\ln \left[\mathrm{L}_{(\mathrm{t})}\right]=\ln \left[\mathrm{L}_{(0)}\right]+\frac{\mathrm{A}_{(0)}}{\mathrm{a}}\left[1-\mathrm{e}^{-\mathrm{a} t}\right]
$$

where $\mathrm{L}_{(\mathrm{t})}=$ length at time $\mathrm{t}_{;} \mathrm{L}_{(0)}=$ length at time zero; $A_{(0)}=$ specific growth rate at time zero; and $a$ = rate of exponential decay of the specific growth rate. The time origin was selected as the hatching time and values of $\mathrm{L}_{(0)}, \mathrm{A}_{(0)}$ and å were obtained by nonbinear regression.

To determine the relationship of age to otolith size and shape, the length, width, and weight of sagittal otoliths were measured. Otoliths were segregated according to their lateral position in the cranium. Left and right sagittae from all fish were scanned using a computeraided video digitizer, which produced a measure of maximum length (from the rostrum to antirostrum, nomenclature of Hecht 1978) and width (the widest distance in the dorsal-ventral plane). Otoliths were weighed on a microbalance to the nearest $0.001 \mathrm{mg}$. 
Measurements were fitted to the multiple regression model:

$$
\text { Age }=a+b_{1} x_{1}+b_{2} x_{2}+b_{3} x_{3}+b_{1} x_{1}
$$

In this model, age in days was determined by counting microincrements, $\mathrm{a}=$ intercept, $\mathrm{b}=$ regression coefficients, $\mathrm{x}=$ variables. The multiple regressions were determined in a stepwise fashion with the inclusion level for variables set at $p=0.05$. In regression analyses, total body length was used as the dependent variable related to number of increments and otolith weight. The use of total body length as the dependent variable is consistent with accepted methodology (Ricker 1973).

From the data on trawl catches and growth, it was possible to estimate natural mortality $(Z)$ in this population of Trematomus newnesi through the model of Beverton \& Holt (1957):

$$
\frac{Z}{k}=\frac{L_{\infty}-\hat{\imath}}{\hat{\imath}-L_{c}}
$$

where $\hat{i}=$ mean length of fish; $L_{c}=$ length at first capture $\mathrm{L}_{\infty}=$ maximum length from von Bertalanffy growth equation; $k=$ estimate from von Bertalanffy growth equation; and $Z=$ instantaneous mortality $\left(N_{t}\right.$ $=\ln N_{0}-Z_{t}$, where $N_{t}, N_{0}$ are population size at times $t$ and 0 , respectively, and $Z_{t}$ is mortality at time $t$ ).

\section{RESULTS}

Larval Trematomus newnesi were regularly observed on the northern shelf of the Antarctic Peninsula in spring of the years $1977 / 78,1983 / 84$, and 1984/ 85 , but the occurrence in the northern Bransfield Strait and around Elephant Island was variable. Length composition was unimodal in 1977, 1983 and 1984 with means of $15.7 \mathrm{~mm}$ (95\% confidence interval 14.4 to $17.0 \mathrm{~mm}), 11.5 \mathrm{~mm}(11.3$ to $11.7 \mathrm{~mm})$ and $16.3 \mathrm{~mm}$ $(14.2$ to $18.5 \mathrm{~mm})$, respectively. Yolk sacs or their residuals were present in $11 \%$ (November/December 1977), 38\% (October/November 1983) and 18\% (November/December 1984) of specimens. During summer and fall of the $1977 / 78$ season, late larval and juvenile fish of 23 to $34 \mathrm{~mm}$ length were caught mostly in shallower areas of the southern Bransfield Strait over bottom depths of 80 to $180 \mathrm{~m}$ (Kellermann 1986a). Transformation occurred at about $30 \mathrm{~mm}$ standard length (SL), and larger specimens showed the complete number of fin ray counts, and all vertebrae had formed. These fishes enabled identification of the whole developmental series (Kellermann unpubl.).

Body length of larvae from all cruises was related to time of capture (Fig. 2). The progression of mean larval

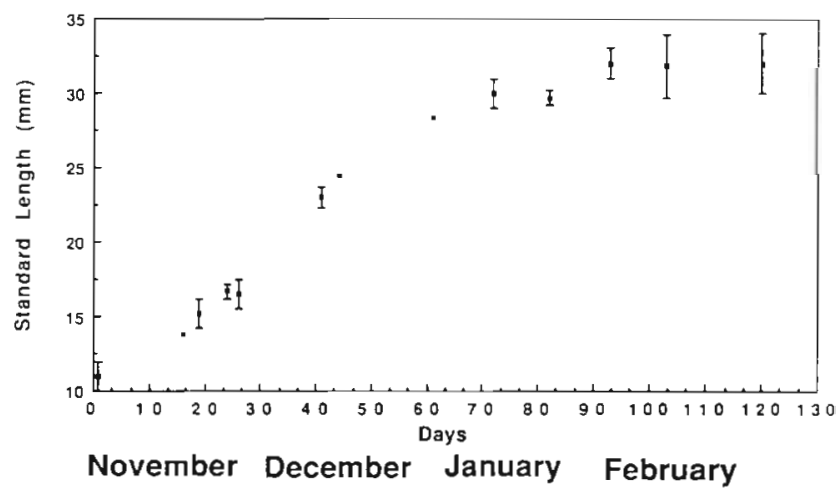

Fig. 2. Trematomus newnesi. Standard length of larvae as related to sampling time. Bars indicate standard deviations. Increase in leng th over time provided an estimate of larval growth

lengths with time of year during capture, is indicative of the growth pattern in these fish. These data suggest that larvae hatched as a cohort prior to November. Thereafter, fish grew rapidly through the first 2 mo of life as larvae, and then reached a gradual plateau after metamorphosis.

The otoliths of larvae were examined from frozen specimens caught in spring 1983. A pronounced check occurred in the center (Fig. 3) at a diameter of ca $40 \mu \mathrm{m}$. This check was postulated to be a hatching disruption and increment counts were taken outward from that point. The core area was separated by a discontinuity and also appeared in adult otoliths (Fig. 4), with a similar diameter. The increment counts outside the core area were used to determine the date of hatching. Increments were counted on otoliths from 7 larval fish captured in early November 1983 (Table 1). The counts suggest that these fish have an estimated hatching time around October 1. This estimate agrees with the Iarval length data (Fig. 2) and the fact that the highest portion of yolk sac stages were observed in October/November.

Juvenile growth rates and dates of hatching were studied in 34 juveniles collected in the shallows (less than $100 \mathrm{~m}$ ) off Low Island on September 18, 1985. These individuals were aged using SEM and light microscopy

Table 1. Trematomus newnesi. Estimated ages from larvae captured from the Bransfield Straight. Increment counts are shown for each of the fish captured and give an estimate of the age and an idea of the follicle spawning time

\begin{tabular}{|lrcc|}
\hline $\begin{array}{l}\text { Date collected } \\
(1983)\end{array}$ & $\begin{array}{c}\text { SL } \\
(\mathrm{mm})\end{array}$ & $\begin{array}{c}\text { Weight } \\
(\mathrm{g})\end{array}$ & $\begin{array}{c}\text { Estimated age } \\
(\mathrm{d})\end{array}$ \\
\hline Nov 1 & 12.0 & 0.00149 & 27 \\
Nov 1 & 9.9 & 000133 & 21 \\
Nov 1 & 12.0 & 0.00147 & 26 \\
Nov 1 & 10.9 & 0.00152 & 22 \\
Nov 1 & 10.0 & - & 20 \\
Nov 6 & 16.9 & 0.00521 & 36 \\
\hline
\end{tabular}




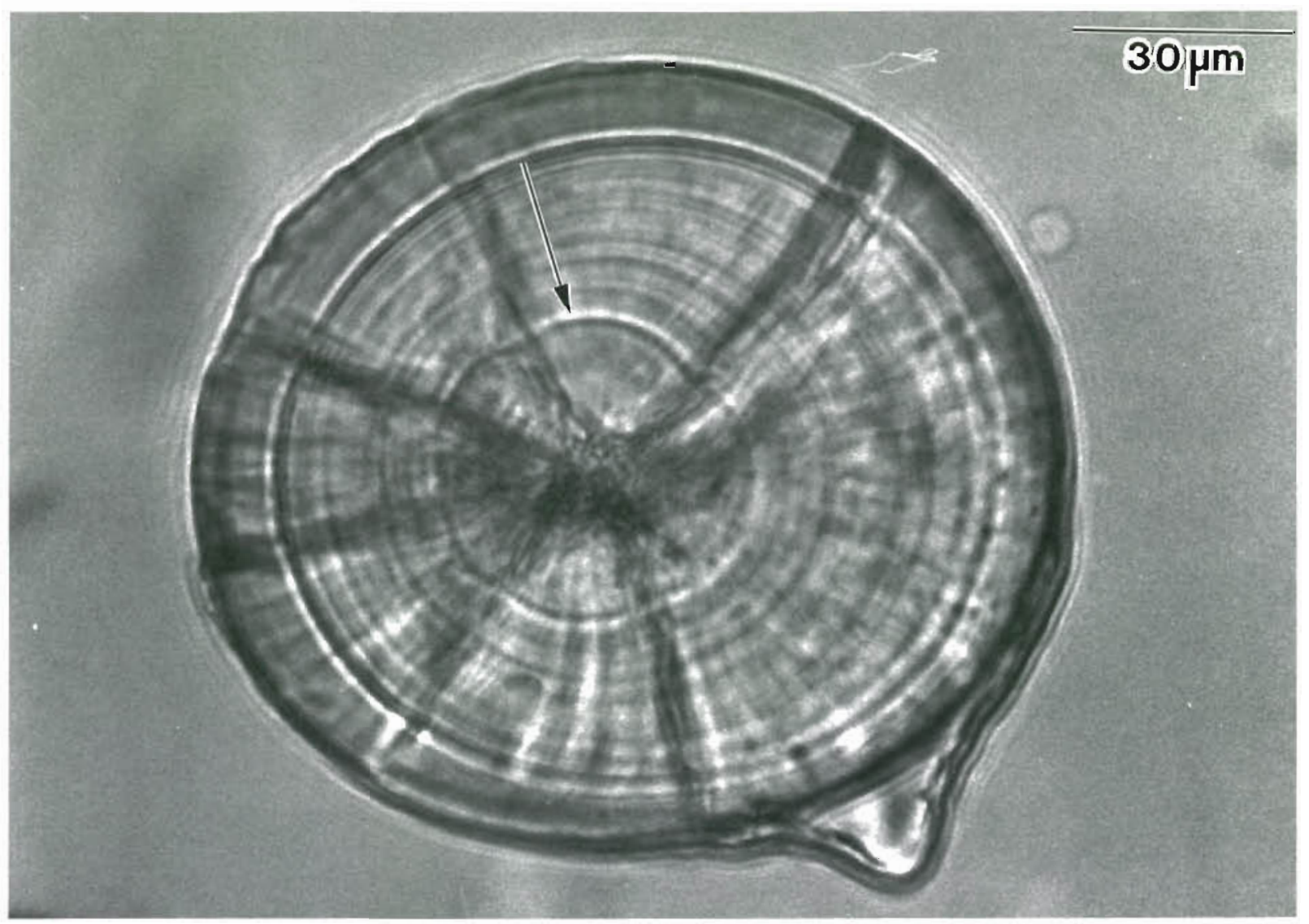

Fig. 3. Trematonus newnesi. Light micrograph of an otolith of a larva (12 mm SL). Microincrements were visible as concentric rings radiating outward from the center. A central core area (arrow) corresponded to the otolith core found in adult otoliths. A second dark band, apparently deposited at about $20 \mathrm{~d}$ after hatching, was also visible

(Fig. 5), and growth followed the Gompertz model (Table 2). Back-calculation to the hatching time of these juveniles demonstrated that these fish hatched between September and November, with peak hatching in October (Fig. 6). This agrees with the larval age data (Table 1). Of the juveniles sampled, none demonstrated a hatching time before September or after November, and hatching in this population of Trematomus newnesi may be limited to September and October.

Over 200 Trematomus newmesi were collected by trawling off Low Island or by hook and line in Arthur

Table 2. Trematomus newnesi. Growth parameter estimates, with $95 \%$ confidence intervals, derived from the Gompertz equation for standard lengths of juveniles

\begin{tabular}{|c|c|c|c|}
\hline \multirow{2}{*}{$\begin{array}{l}\text { Para- } \\
\text { meter }\end{array}$} & \multirow{2}{*}{$\begin{array}{l}\text { Estimated } \\
\text { value }\end{array}$} & \multicolumn{2}{|c|}{ Confidence limits } \\
\hline & & Lower & Upper \\
\hline$L_{(0)}$ & $3.73 \mathrm{~mm}(\mathrm{SL})$ & $-56.14 \mathrm{~mm}$ (SL) & $63.61 \mathrm{~mm}$ (SL) \\
\hline$A_{(0)}$ & 3.09 & -11.01 & 17.19 \\
\hline $\mathrm{a}^{1,3}$ & .006 & -0.021 & 0.032 \\
\hline$r^{2}$ & 0.99 & & \\
\hline
\end{tabular}

Harbor. Fish were caught in shallow trawls 50 to $100 \mathrm{~m}$ in depth. Fish captured in trawls ranged in size from 45 to $185 \mathrm{~mm} \mathrm{SL}$, and the distribution of size classes is given in Fig. 7. The middle age groups were dominant in the summer samples while younger age groups were dominant in the winter samples. Sampling bias may be present due to the iact that $T$. newnesi is a cryopelagic rather than a purely demersal species and, as a result, may more easily avoid net collections.

For Trematomus newnesi, weight is approximately a cubic function of standard length, indicating nearly isometric growth. The relationship between total wet body weight (W) in grams and standard length (SL) in millimeters is best described by a power function regression of these 2 variables: $W=a(S L)^{b}$ where $a$ and $b$ are constants. No difference between the sexes was observed and the values $a$ and $b$ were derived from $a$ $\log _{10}$ transformation and least squares fit:

$$
W=0.00003(S L)^{3.906} \quad\left(n=216 ; R^{2}=0.99\right)
$$

The conversion of standard length (SL) to total length (TL) was:

$$
\mathrm{TL}=1.139(\mathrm{SL})+2.940 \quad\left(n=216 ; R^{2}=0.99\right) .
$$




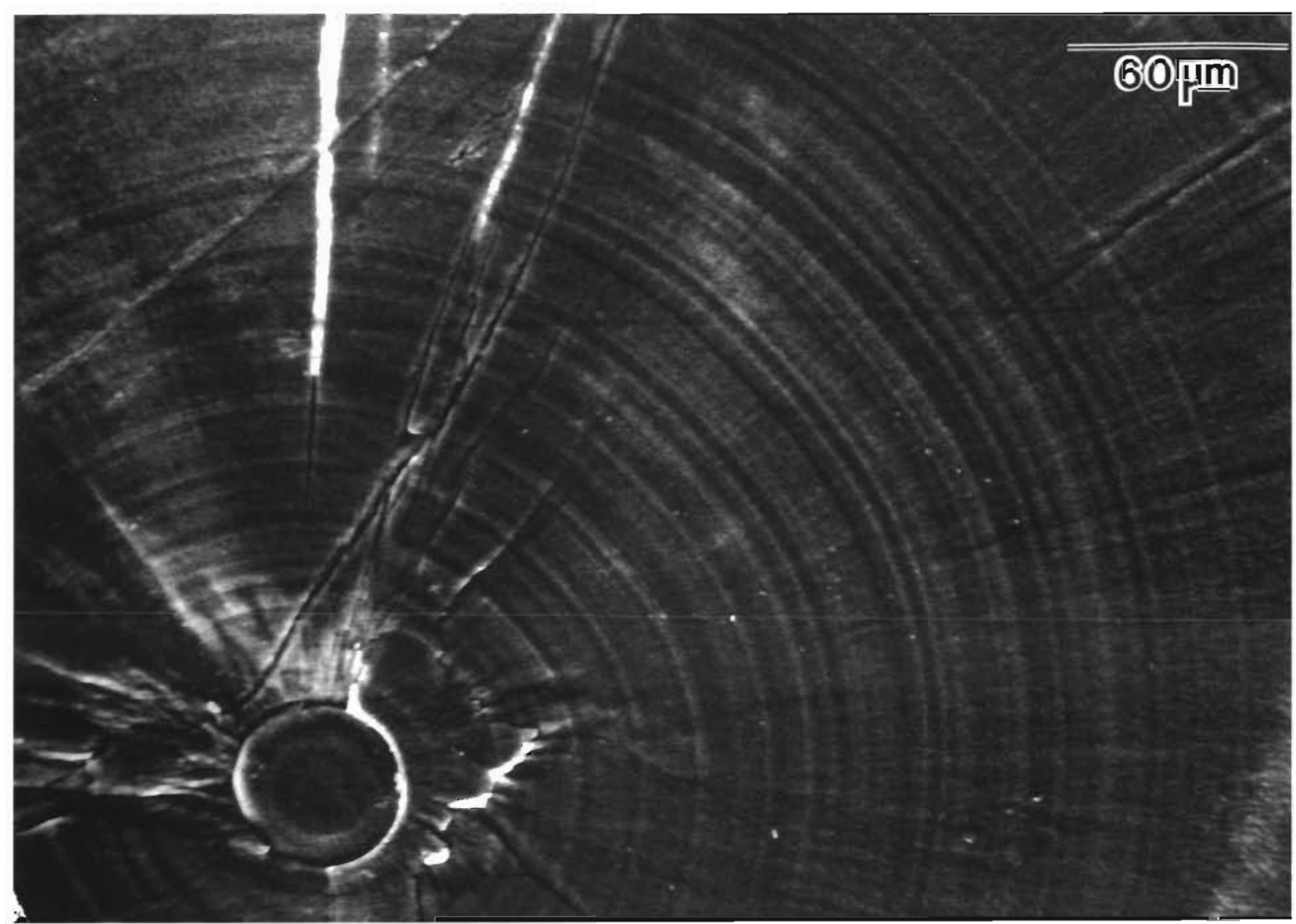

Fig. 4. Trematomus newnesi. Scanning electron micrograph of a sagittal otolith of an. adult, which demonstrated a central core area and microincrement deposition. The core was separated by a well-defined transitional zone from the outer zone and microincrements were found within the core area

Otolith size and weight were related to fish size. The sagittae of Trematomus newnesi were small and generally square in shape (Fig. 8), with a rounded rostrum (nomenclature from Hecht 1978, Morrow 1979). The rostrum was more pronounced in larger fish. A shallow sulcus was transected by a collum and terminates to form a slight excisural notch accentuated by the rostrum and

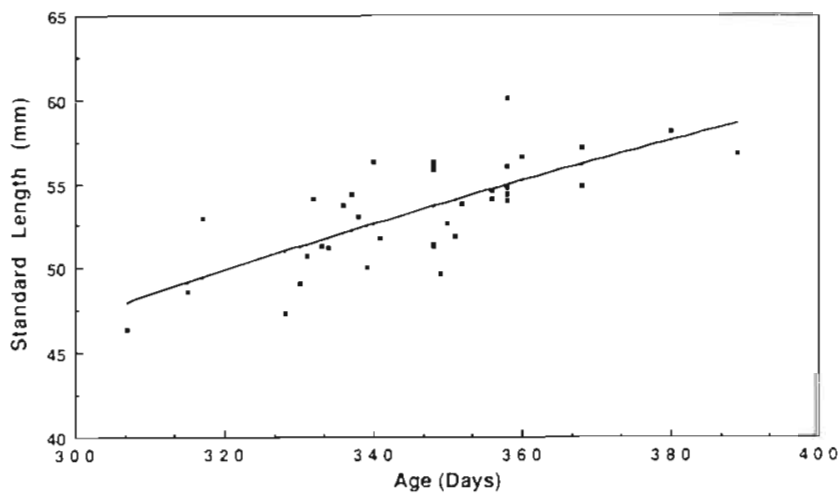

Fiq. 5. Trematomus newnesi. Age estimation for juventles as determined by daily otolith increments. The data were fitted to the Gompertz model, as shown by the line antj-rostrum. The core region of the otolith was in the collum area. The external surface was smooth and gently rounded. The external features of $T$. newnesi otoliths were distinctive compared to those from other Antarctic fishes examined (Chaenocephalus aceratus, Champsocephalus gunnari, Notothen angustifrons, and N. gib-

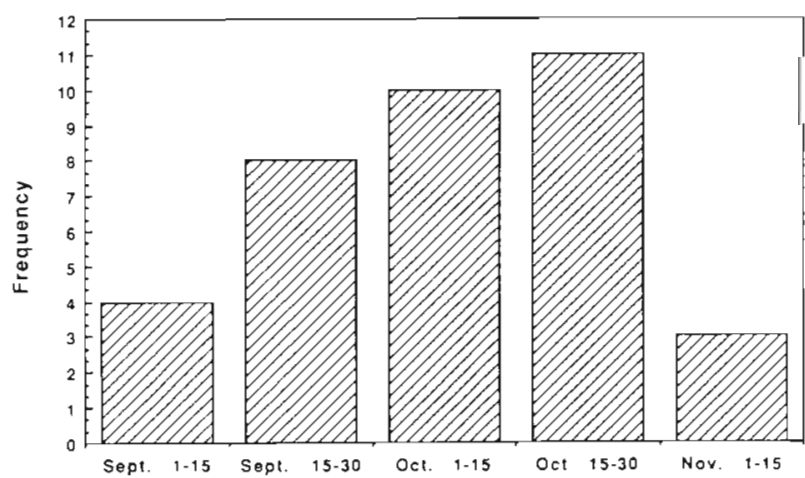

Fig. 6. Trematomus newnesi. Estimated time of hatching. Estimates were the result of back-calculations of hatching, based on the number of microincrements between the core and the outer edge of the sagittal otolith in juveniles 


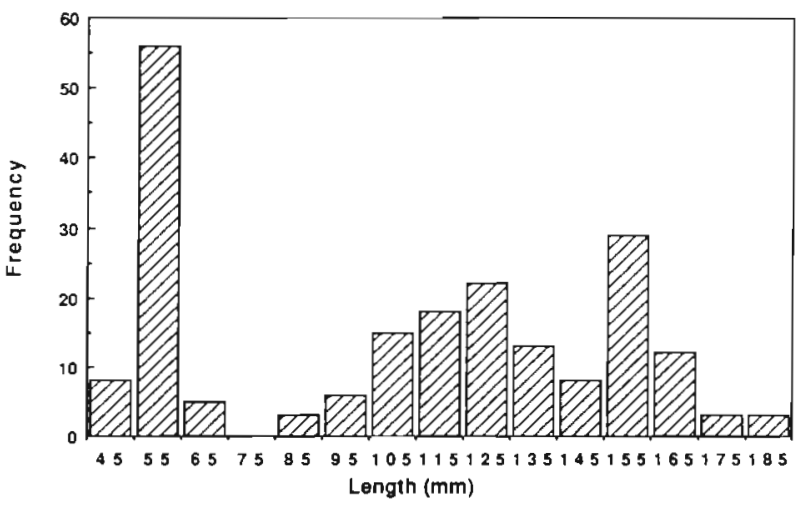

Fig. 7. Trematomus newnesi. Length frequency distribution of fish captured during the study in 1985 . Several size modes were missing from the collections

berifrons) (Radtke pers. obs.). A linear relationship was found between sagitta length and fish SL:

$$
\begin{gathered}
\text { Sagitta length }(\mathrm{mm})=0.015(\mathrm{SL})+0.099 \\
\left(n=216 ; R^{2}=0.97\right)
\end{gathered}
$$

Fish SL was related logarithmically to sagitta weight and described by the equation:

$$
\begin{gathered}
\text { Sagitta weight }(\mathrm{mg})=3.97(\mathrm{ln} \mathrm{SL})-16.68 \\
\left(n=216 ; R^{2}=0.99\right) .
\end{gathered}
$$

Validation experiments for Trematomus newnesi showed that increment formation in otoliths occurred daily in laboratory experiments. Otoliths from tetracycline-injected $T$. newnesi showed a distinct tetracycline mark when viewed with ultraviolet light, and this mark

Table 3. Trematomus newnesi. Results of validation experiments where fish were injected with $25 \mathrm{mg} \mathrm{kg}^{-1}$ tetracycline. fed ad libitum and kept in the laboratory under natural light conditions (16L/8D). Otoliths were viewed by light microscopy with UV light

\begin{tabular}{|rcc|}
\hline SL (mm) & $\begin{array}{c}\text { Days after } \\
\text { tetracycline injection }\end{array}$ & $\begin{array}{c}\text { Increments after } \\
\text { tetracycline mark }\end{array}$ \\
\hline 115 & 33 & 33 \\
62 & 33 & 35 \\
108 & 33 & 32 \\
116 & 33 & 33 \\
110 & 33 & 32 \\
116 & 33 & 33 \\
131 & 33 & 30 \\
117 & 33 & 33 \\
109 & 33 & 32 \\
96 & 33 & 34 \\
104 & 33 & 32 \\
125 & 33 & 31 \\
155 & 153 & 150 \\
151 & 153 & 149 \\
154 & 153 & 150 \\
150 & 153 & 148 \\
145 & 52 & 51 \\
\hline
\end{tabular}
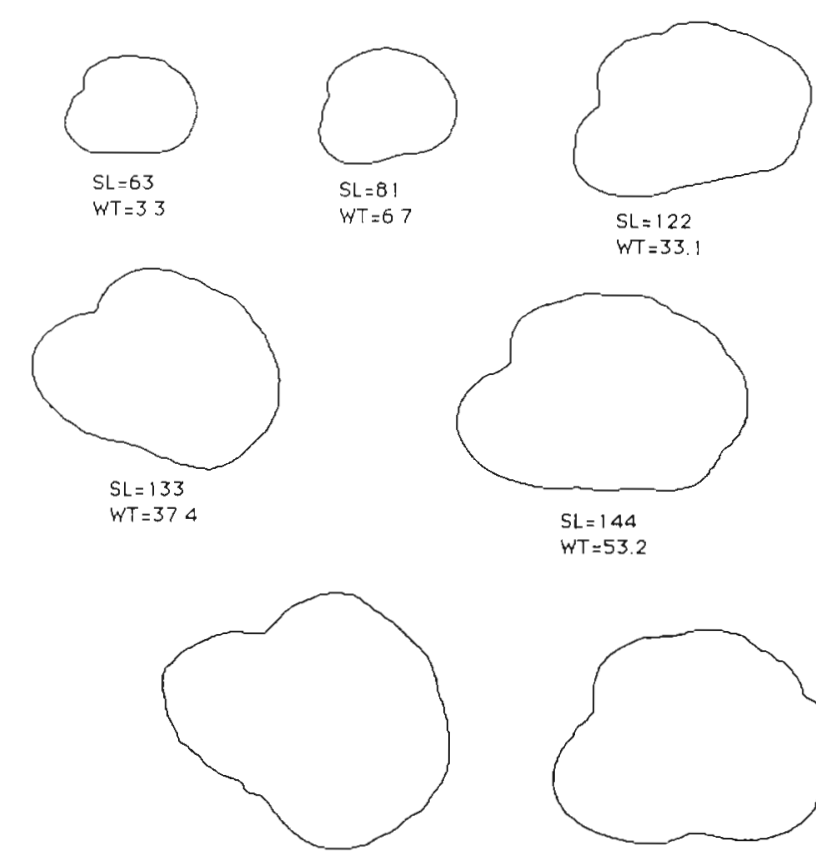

$S L=150$
$W T=676$

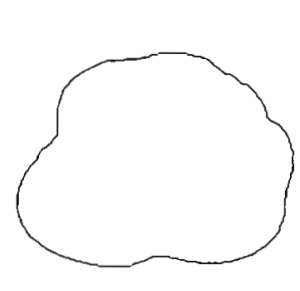

$S L=179$

$W T=113.6$

$1 \mathrm{~mm}$

Fig. 8. Trematomus newnesi. Change size and shape of sagittal otoliths with increasing fish size. SL: standard length; WT: wet weight of fish

was followed by microincrements (Fig. 9). After injection with tetracycline, $T$. newnesi displayed evidence of short-term stress, including cessation of feeding for 2 or 3 d. Subsequently, the fish survived well in captivity, with a small number of fish surviving through the winter. Sagittae of 30 fish, injected with tetracycline in February and March 1984 and held 33 to $153 \mathrm{~d}$ under ambient daylight photoperiods, were examined for post-treatment increments. A discrete fluorescent band was discernible in all specimens, and increments between the band and the margin of the otolith were counted (Table 3). The agreement between the number of increments and the number of days after injection was good, averaging 1.3 increments less than the number of days. These results provide verification that the microincrements of $T$. newnesiare deposited daily even in the winter, despite considerable variation in photoperiod.

Through the use of daily increments, it was feasible to age Trematomus newnesi. No annuli could be discerned. Otolith sections viewed by light microscopy displayed both large and small scale incremental patterns, which were difficult to interpret. Examinations made with SEM showed distinct microincrements (Fig. 10). Increment width varied, and microincrements less than $0.2 \mu \mathrm{m}$ wide were seen by SEM. This range in widths probably reflects differences in daily growth 

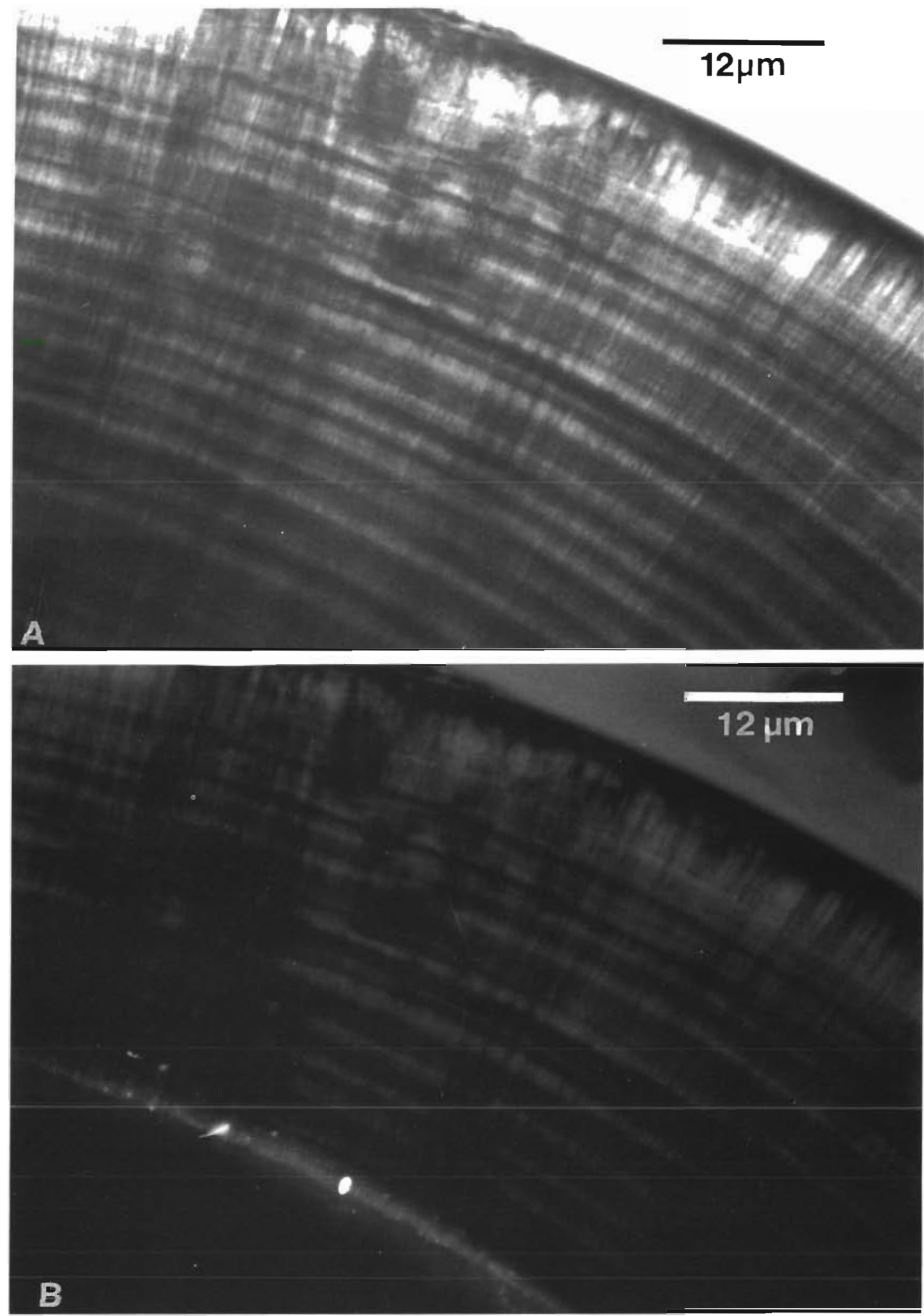

Fig. 9. Trematomus newnesi. Light photomicrographs of the sagitta of fish with a total body length of $185 \mathrm{~mm}$ and a body weight of $72.2 \mathrm{~g}$. This fish was injected with $25 \mathrm{mg} \mathrm{kg} \mathrm{kg}^{-1}$ of tetracyline and sacrificed later. (A) Photograph under visible light; (B) photograph demonstrating the tetracycline band when. the otolith is viewed with ultraviolet light 
Table 4. Trematomus newnesi. Growth parameter estimates, with $95 \%$ confidence intervals, derived from the von Bertalanffy equation for standard length

\begin{tabular}{|c|c|c|c|}
\hline \multirow{2}{*}{$\begin{array}{l}\text { Para- } \\
\text { meter }\end{array}$} & \multirow{2}{*}{$\begin{array}{c}\text { Estimated } \\
\text { value }\end{array}$} & \multicolumn{2}{|c|}{ Confidence limits } \\
\hline & & Lower & Upper \\
\hline $\mathrm{L}_{*}$ & $194.77 \mathrm{~mm}$ (SL) & $150.5 \mathrm{~mm}$ (SL) & $239.05 \mathrm{~mm}$ (SL) \\
\hline $\mathrm{k}$ & $0.001 d^{-1}$ & $0.0003 \mathrm{~d}^{-1}$ & $0.002 \mathrm{~d}^{-1}$ \\
\hline $\begin{array}{l}t_{0} \\
R^{2}\end{array}$ & $\begin{array}{c}-14.99 \mathrm{~d} \\
0.99\end{array}$ & $-248.5 d$ & $218.6 \mathrm{~d}$ \\
\hline
\end{tabular}

rates. Closer examination (Fig. 11) revealed that the increments were alternating protein ridges, made visible by use of EDTA (EDTA chelates $\mathrm{CaCO}_{3}$ while leaving the protein unchanged). Once the correct plane and etching time were determined, the microincrements could be counted regardless of width. Surrounding the core area were mineral crystals in a protein matrix which formed microincrements. This relationship demonstrates the potential of each microincrement to reflect a growth interval related to fish size and consistent with growth processes.

Age estimates were derived from SEM counts of growth increments counted in the sagittal otoliths of 32 adult fish. Ages ranged from less than 1 yr for small juveniles, to $7 \mathrm{yr}$ for the largest individual collected. Recruitment into the adult population occurs at ca 1 yr. Fish length was related to the number of microincrements in the sagitta (Fig. 12). The data were then fitted to the von Bertalanffy growth equation, resulting in the growth curve shown in Fig. 12. The estimated values for the von Bertalanffy parameters and their confidence limits are given in Table 4 . Some variation in grow th rate was observed and the smallest fish was not always the youngest. This population grows at a relatively rapid rate during the early years with a leveling off during the last growing seasons. There was a steady, gradual, almost linear increase in length through the maximum age
Age was strongly associated with fish size and otolith morphometrics. Multiple regression analysis relating fish size, otolith weight and length, and age at the $p<0.02$ significance level resulted in the acceptance of the following model:

$$
\begin{gathered}
\text { Age }=496.32-228.91 \text { Sagitta length }+512.9 \text { Sagitta } \\
\text { weight }-3.33 \text { SL. }
\end{gathered}
$$

Stepwise multiple regression analysis of body weight, SL, TL, otolith weight, otolith length, and otolith width determined that standard length, body weight, and sagitta weight measurements were the most important parameters in predicting age. The variables within the present model were significant (Table 5) and the coefficient of determination was 0.98. Addition of the remaining variables did not improve the regression significantly. Over $97 \%$ of the variance was explained by the regression of the 2 otolith measurements (weight and length). The residuals were randomly distributed which demonstrated that this multiple regression best explains the variability in age. Therefore, in Trematomus newnesi it appears that age can be reliably determined from body measurements and otolith weight and length. This approach could have a central application in fishery statistics.

The variables in the model are not strictly independent. This deviation from the assumptions of the model may result in an artificially inflated $R^{2}$ value, however, this should not decrease their practical value as predictors. Sagitta weight alone accounted for $95 \%$ of the variance in the regression, supporting the usefulness of otoliths as structures reliably related to age. The relationship between otolith dimensions, age and fish size are seen in the preceeding figures. Indeed, the most significant variable related to age is sagittal weight, although sagittal length and standard length of the fish can add to the reliability of these equations and, consequently, add to decreasing the error associated with age prediction.

\begin{tabular}{|c|c|c|c|c|c|}
\hline \multicolumn{6}{|c|}{ Analysis of variance } \\
\hline Source & $\mathrm{df}$ & Sums of squares & Mean squares & $F$ & $p>F$ \\
\hline Between groups & 3 & 572.88 & 190.96 & 143.12 & 0.0001 \\
\hline Within groups & 28 & 146.91 & 13.34 & & \\
\hline Total & 31 & 587.56 & & & \\
\hline \multicolumn{6}{|c|}{ Type II model } \\
\hline Variable & $\mathrm{SE}$ & \multicolumn{2}{|c|}{$I^{2}$} & $F$ & $p>F$ \\
\hline Sagitta weight & 66.9 & \multicolumn{2}{|c|}{0.95} & 58.76 & 0.0001 \\
\hline Sagitta length & 149.86 & \multicolumn{2}{|c|}{0.97} & 2.33 & 0.1449 \\
\hline Standard length & 3.13 & \multicolumn{2}{|c|}{0.98} & 1.12 & 0.3120 \\
\hline
\end{tabular}

Table 5. Trematomus newnesi. Associated statistics on the multiple regression model of age. $n=32$ 

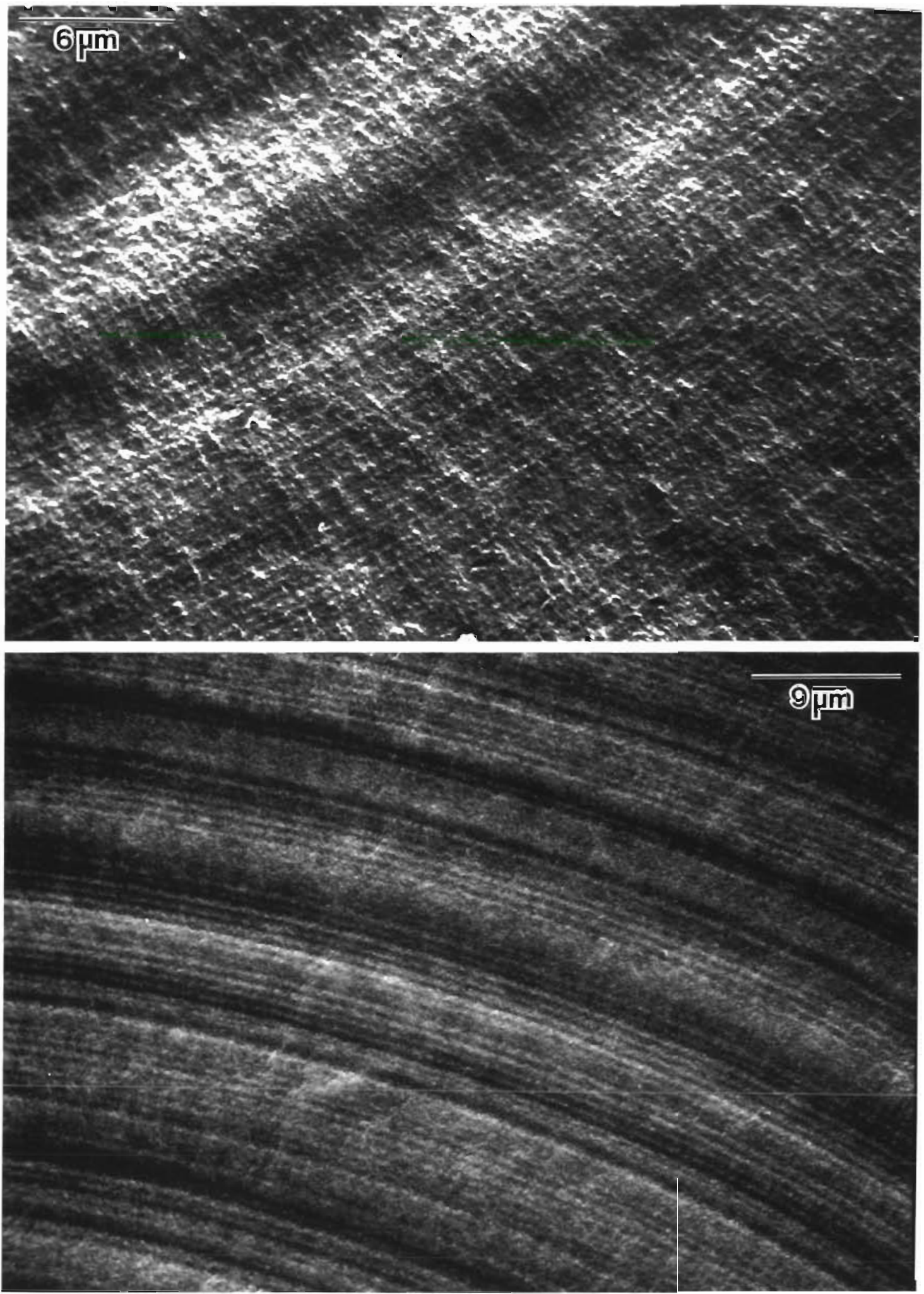

Fig. 10. Trematomus newnesi. Scanning electron micrographs of microincrements of a sagittal otolith, as utilized for daily increment enumeration. These microincrements were indicative of the small size of the individual increments and of the patterns found in otoliths. Increments found in lower micrograph are indicative of faster growth 


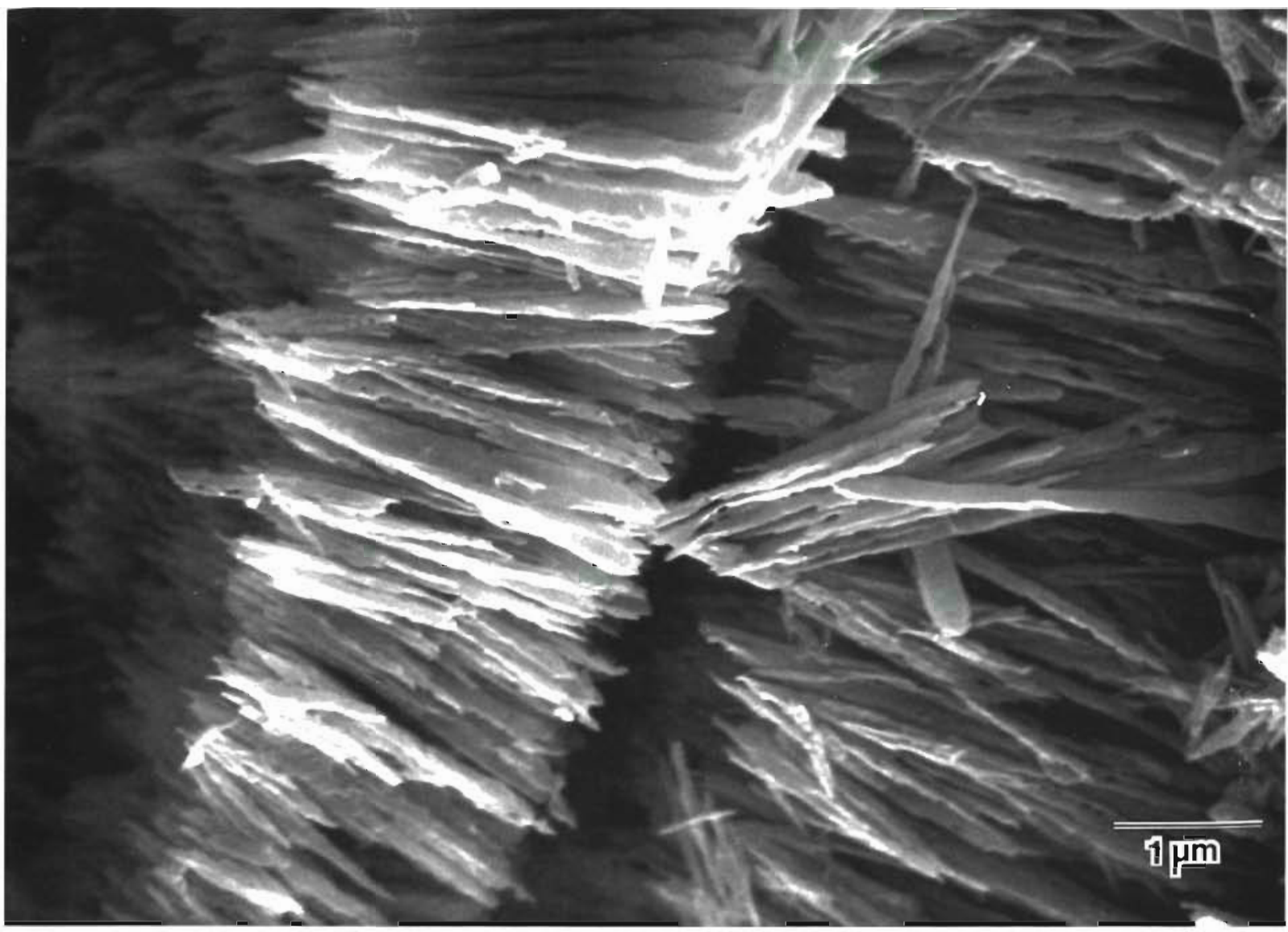

Fig. 11. Trematomus newnesi. Scanning electron micrograph of a growth increment of a sagittal otolith, as utilized for daily increment enumeration, that displays aragonite crystals in a protein matrix. These components comprise the incremental and discontinuous zones

The relationship between age and otolith morphometrics allowed the estimation of age for all the fish in the sample. No difference was found between ages estimated from otolith increments and ages estimated from otolith morphometrics $(p<0.05)$. As a measure of

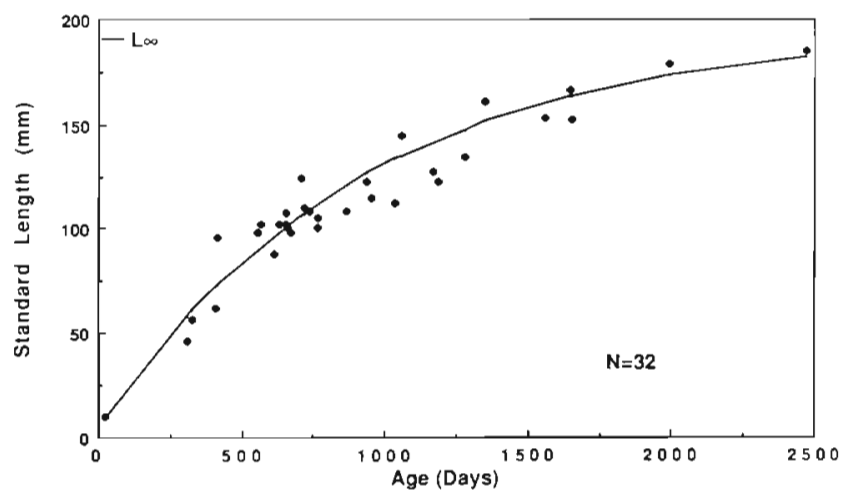

Fig. 12. Trematomus newnesi. Relationship of fish standard length (SL) to age as determined from the number of sagittal otolith microincrements. Von Bertalanffy growth curve was based on daily increment counts from sagittae of 32 specimens viewed with a SEM the variance associated with this procedure, the percent of the total variance component due to variance between age estimates from the left and right sagittae of the same fish was calculated. This variance was $p<0.05$ due to variance between sagittae of the same fish.

The Beverton and Holt estimate of natural mortality in this population of Trematomus newnesl, derived from the sample of 32 fish of estimated ages, yielded a value of $Z=0.45$ (95\% confidence limits 0.36 to 0.48 ). When the value was calculated using the von Bertalanffy growth parameters for the larger sample of 237 fish with predicted ages, the value was $Z=0.44(95 \%$ confidence limits 0.35 to 0.46 ). Mortality for individual year classes ranged from 0 to 0.79 . Mean rates were similar between groups.

\section{DISCUSSION}

The Antarctic ecosystem has been geographically isolated for 40 to 60 million yr. The coastal waters of the Antarctic Oceans are colder and thermally more stable than the waters in the Arctic (DeWitt 1971), making it 
difficult to extrapolate from one ecosystem to the other. The effects of higher predators, particularly fish, must be taken into account to understand the functioning of the Antarctic marine ecosystem. Hassel (1976) demonstrated that predators can have both stabilizing and oscillating influences on marine ecosystems, particularly in an ecosystem which does not undergo wide environmental oscillations. Fish may, therefore, be an important factor in determining how the Antarctic marine ecosystem functions, yet there remains a paucity of information on fish population dynamics. Population studies require either long-term sampling programs or life history profiles on individual fish. Historical information about events that occurred earlier in the life of a fish can be obtained from within the individual itself.

The present study used otolith ageing techniques to investigate life history in Trematomus newnesi. Daily increment analyses cannot answer all questions of Antarctic fish biology, but j.t does make it feasible to age an individual fish and reconstruct a record of its past. The otoliths of $T$. newnesi contain microincremental growth rings, which can be counted using SEM techniques, Radtke \& Targett (1984) compared microincrements in the otoliths of Nototheniops larseni to growth curves from scale annuli (data from Shust \& Pinskaya 1978), and found that the latter significantly underestimated ages of fish throughout the size ranges studied.

Validation of increment formation is a necessary prerequisite to ageing studies of any kind. The antibiotic tetracycline complexes in vivo with calcified tissues providing a permanent fluorescent mark. Thus, tetracycline makes it practicable to validate the time scale of growth patterns of calcified structures (Weber \& Ridgeway 1967). The validation data presented showed that increments were formed on a daily basis. There was no evidence that daily increment formation did not continue throughout the year for $I$ newnesi. Increment formation appeared to continue despite the lack of environmental cues in times of constant light and constant dark, and that the daily periodicity in these fish may be associated with prior information about their life cycles. Handling associated with the tetracycline injections has the disadvantage of stressing the fish. which may explain the $1.3 \mathrm{~d}$ lag period before increment formation resumes. Because of the lack of distinct annuli, daily increments in otoliths furnish the best avenue for age resolution for Antarctic fishes.

Although we validated the daily nature of microincrement deposition, there may be some areas in the otolith where non-daily deposition occurs. Subdaily growth increments, although infrequent, have been encountered in fish otoliths. They have been found primarily in portions of fish otoliths deposited during the rapid early stages of larval and juvenile growth, and in otoliths of tropical fishes within thick increments (ca $10 \mu \mathrm{m}$ ) deposited during rapid growth (Pannella 1980, Radtke 1984). However, no exceptionally wide increments were observed in Trematomus newnesi sagittae. If, on the other hand, microincremental growth rings are deposited less trequently than daily, as growth rate slows in older fish or for the portions of each year when the 24 h light-dark cycle is indistinct or lacking in the Antarctic, then age estimates from microincrement counts would underestimate rather than overestimate age. Although areas in otoliths were detected in which increment width decreased, none of these appeared to indicate cessation of increment formation. Therefore, we conclude that in $T$. newnesi microincrement counts appear to reflect the fish's age in days.

Otoliths are usually characterized by one or more transition zone or check. Trematomus newnesi sagittae had a distinct check at the core, which appeared to mark hatching. Analysing other transition zones in young Antarctic fishes may be helpful in determining the significance of growth checks in otoliths of longlived species. Developmental stages during the first year of $T$ newnesi include hatching into a yolk-sac stage and absorption of the yolk sac coupled with feeding initiation. The latter may also be recorded in the otoliths. This latter stage has been called the critical period. Mortality rates may increase drastically at this time due to starvation because the young larvae are very inefficient feeders. Here too, the otolith record may reveal the stress associated with initially low feeding rates (Methot \& Kramer 1979, Radtke \& Waiwood 1980). As hatching periods are reflected in the otolith structures of most species, the presence of such marks may allow the determination of spawning frequency and duration. Furthermore, otoliths act as a register of the environmental conditions experienced by the fish during its lifespan. Otolith materials are laid down in equilibrium with the environment and are not removed or absorbed. More detailed analyses, including chemical analyses, may lead to additional life-history information of $T$. newnesi and other Antarctic fishes.

Fish growth is a continuous process which is inversely related to age. Internal factors (spawning, physical stress) as well as external factors (temperature, food) act upon growth, causing cyclic variations. These fluctuations affect the development of calcified tissues and are registered as growth increments. During favorable periods of fast growth, an area rich in protein is laid down in the otoliths. Therefore, it is not suprising that otolith size is related to fish size, and that the width of the individual increments may be closely correlated with fish growth. Otolith structural data can thus provide information on biological periods and growth fluctuations in the fish on a daily basis.

The conservative nature of otoliths is demonstrated by 
the sagittal length to standard length relationship. The otoliths grow in a linear fashion and these structures may be useful in age determination. Other characteristics of otoliths, such as weight, could provide additional information on the ecology of Trematomus newnesi. Otolith weight appears to be a direct corollary of fish age, since weight and age are related to fish length in a similar fashion. Sagittal otolith weights were related logarithmically to fish size. There was evidence that fast-growing (younger) fish have lighter otoliths at a given body weight than do slow-growing (older) fish. Thus, it may be possible to compare otolith weights to fish size and arrive at quick estimates of relative age.

Trematomus newnesi is a commonly encountered shallow water fish along the Antarctic Peninsula and is one of the few fishes found in the pelagic zone aside from Pleuragramma antarcticum. T. newnesi has been reported in the Atlantic Sector of the Southern Ocean, from the South Orkney and South Shetland Islands (Permitin 1977), Elephant Island (Kock 1982) and from the northern shelf of the Antarctic Peninsula where it is a common species (Daniels 1982). However, it was not encountered on the northern shelf of the South Shetland Islands during an extensive bottom trawl survey by Japanese vessels (Iwami \& Abe 1982). From our results, several conclusions can be drawn. the southern shelf areas of the Bransfield Strait, from the eastern Palmer Archipelago to the tip of the Antarctic Peninsula, can be regarded as spawning areas as indicated by the distribution and abundance of larvae. Catches of later stages were almost exclusively confined to the shallower part of the shelf. Hence, the late larval stages appear to already migrate from the open waters towards the inshore parts of the Strait in January and February, where they may settle down in March to what is termed the benthic phase. Early age groups and adult spawning groups were mainly sampled in the shelf water, while the juvenile pre-adults and the younger juveniles were probably elsewhere. These missing size classes may be verified through further research. Our data suggest that T. newnesilarvae and young stay in the shelf waters and move into deeper water later.

Spawning and hatching probably occur in shallow waters. Hatching in shallow waters has been observed to be partly triggered by degree of ice cover in Harpagifer bispinis (Daniels 1978). Our data indicate that Trematomus newnesi larvae hatch in September and October, but it is not clear how this is related to ice cover. Spawning in shallow waters (i.e. less than $160 \mathrm{~m}$ ) by $T$. newnesi could account not only for the inconsistency of length frequencies, but also for the 'retarded' lengths of Everson's (1968) specimens, which were caught in Borge Bay at a depth of $2 \mathrm{~m}$. He reported these to be 13.7 to $19.0 \mathrm{~mm}$ in length in January. Everson (1969) reported juvenile T. newnesi of 56 to $125 \mathrm{~mm}$ standard length to occur at the South Orkneys all year. Nybelin (1947) gives standard lengths of 63 to $66 \mathrm{~mm}$ for fish caught off Graham Land in January inshore. Nybelin's and Everson's small fish were probably 1 yr old.

Feeding occurs throughout the year in most fishes examined from the Antarctic Peninsula (Daniels 1982), and activity of fishes does not appear to decrease during the winter (Hourigan \& Radtke unpubl.). Yearround feeding may in part assure the daily deposition of increments in spite of the short winter photoperiods. The feeding habits of Trematomus newnesi are reported from several localities to be benthopelagic to pelagic, but the fish have also been frequently observed entering the water column to feed actively at the undersurface of sea ice (Richardson 1975, Targett 1981, Daniels 1982). Consequently, T. newnesi was classified among the cryopelagic species (Andriashev 1965, DeVries \& Eastman 1982).

Trematomus newnesi is characterized by slow growth, long life and high survivorship. It has become increasingly obvious that as age and growth studies on Antarctic fish proliferate, slow growth and long life will be the norm. Other Antarctic fish species which attain small maximum sizes, such as Nototheniops larseni and Harpagifer bispinis, also grow slowly. Growth in $T$. newnesi larvae followed the Gompertz curve. Bolz \& Lough (1988) found that haddock Melanogrammus aeglefinus and Atlantic cod Gadus morhua larvae also conformed to Gompertz growth equations, whereas the adults followed von Bertalanffy equations. In T. newnesi recruitment of 1 -yr-old fish was most common in the late winter in the shallow areas, and fish were found to be as old as 7 yr The growth curve for adult $T$ newnesi was determined in terms of standard body length vs otolith weight, and total body length vs microincrement counts. Although growth of the population was defined by the von Bertalanffy equation, adult fish continued to grow at a slow rate. Therefore, in order to provide a more general treatment, asymptotic length should be assumed to vary within the population about a mean of $L_{x}$. with a probability density function.

A comparison of the variability of the Gompertz and von Bertalanffy models can be misleading. The Gompertz equation shows a greater relative variability because it relates to a finer scale of age than the von Bertalanffy equation. Larval growth determinations are variable, which could well be the result of the variance in growth between individuals. Consequently, this would lead to wide confidence intervals for the length at sub-0. The Gompertz equation has been used for many fish species (e.g. Bolz \& Lough 1988), often without regard to confidence intervals. Confidence intervals, while not taking away from the results, do show the variability which may exist in the data. Because of 
inherent differences in fish growth rates, the variability in the present study may be representative of what is found in the population. The results from the Gompertz equation can be utilized for comparative purposes and the confidence intervals are necessary to understand the variability in the sample.

Survival of fish within a population is dependent on a number of intrinsic and extrinsic factors. Instantaneous natural mortality averaged 0.46 for Trematomus newnesi. This estimate is within the range reported for other Antarctic species (Kock et al. 1985, Radtke \& Hourigan 1989). There is some indication that fish of different sizes have different mortality rates. To fully understand recruitment of fish populations, it is necessary to understand the relative importance of the various types of mortality, and how they might affect fish at different ages. It is important to study both densitydependent and density-independent survival determinants. In many fish populations, the life-history strategy of producing large numbers of young, which undergo large mortality, results in only a small percentage surviving to become adults. This strategy suggests that changes in mortality in larval stages can greatly affect the subsequent population size.

In conclusion, the study of otolith microstructure and morphometry in Trematomus newnesi provided information on the population dynamics of this fish. The data presented indicate that otolith increments were deposited daily, which made it feasible to obtain age estimates. From the age data we determined that hatching appeared to be limited to 2 mo in the spring, recruitment into the adult population occurred at $1 \mathrm{yr}$ of age and natural mortality rates were estimated at 0.46 . Future studies may reveal that there are more life history data recorded in $T$. newnesi sagittae. Otolith analyses are invaluable to population, ecological and evolutionary studies, and would supply a new level of knowledge for fisheries biologists. Otolith studies must be considered when plans for Antarctic fisheries are being developed, and also when determining any changes in ecosystem components.

Acknowledgements. Thanks are due to the staff of Paimer Station and $\mathrm{T}$ Hourigan for help in collections and rearing. C. Rowland and S. Folsom helped with sample preparation and data analyses. P. Lenz and B. Tilley provided editorial assistance. This research was supported by NSF Grants DPP.8214492, DPP 85-21017 and DPP 88-16521 This is Hawau Institute of Geophysics contribution No. 2167.

\section{LITERATURE CITED}

Andriashev, A. P. (1965). A general review of the Antarctic fish fauna. In: van Mieghem, J., Van Oye, J. (eds.) Biogeography and ecology of Antarctica. Junk Publ., The Hague, p. 491-550
Beverton, R. J. H., Holt, S. J. (1957). On the dynamics of exploited fish populations. Fishery Invest., Lond. (Ser. 2) 19: $1-533$

Bolz, G. R., Lough, R. G. (1988). Growth through the first six months of Atlantic cod, Gadus morhua, and haddock, Melanogrammus aeglefinus, based on daily otolith increments. Fish. Bull. U. S. 86 (2): 223-235

Brothers, E. B. (1982). Aging reef fishes, NOAA. Tech. Mem., U. S. Dept. of Congress NMS-SEF-80: 3-23

Burchett, M. S., DeVries, A., Briggs, A. J. (1984). Age determination and growth of Dissostichus mawsoni (Norman, 1937) (Pisces, Nototheniidae) from McMurdo Sound (Antarctica). Cybium 8: 27-31

Campana, S. E., Neilson, J. D. (1985). Microstructure of fish otoliths. Can. J. Fish. Aquat. Sci. 42: 1014-1032

Daniels, R. A. (1978). Nesting behaviour of Harpagifer bispinis in Arthur Harbour, Antarctic Peninsula. J. Fish. Biol. 12: $465-474$

Daniels, R. A. (1982). Feeding ecology of some fishes of the Antarctic Peninsula. Fish. Bull. U. S. 80 (3): 575-588

Daniels, R. A. (1983). Demographic characteristics of an Antarctic plunderfish, Harpagifer bispinis antarcticus. Mar. Ecol Prog. Ser 13: 181-187

Daniels, R. A., Lipps, J. H. (1982). Distribution and ecology of fishes of the Antarctic Peninsula. J. Biogeogr. 9: 1-9

DeVries, A. L., Eastman, J. T (1982). Physiology and ecology of notothenioid fishes of the Ross Sea. J. R. Soc. N. Z. 11 (4): $329-340$

DeWitt, H. H. (1971). Coastal and deep-water benthic fishes of the Antarctic. Antarct. Map Folio Series 15: 1-10

DeWitt, H. H., Hureau, J. C. (1979). Fishes collected during "Hero" cruise 72-2 in the Palmer Archipelago, Antarctica, with the description of two new genera and three new species. Bull. Mus. Natn. Hist. Nat., Paris, Ser 4 Sect 1 A $775-820$

Everson, I. (1968). Larval stages of certain Antarctic fishes. B. Antarctic Surv. Bull. 16: 65-70

Everson, I. (1969). Inshore fishes from the South Orkney and South Shetland Islands, The Antarctic Peninsula and South Georgia. Br Antarct. Surv. Bull. 19: 89-96

Hassel, M. P. (1976). The dynamics of competition and predation. Edward Arnold Publ. Ltd, London

Hecht, T (1978). A descriptive systematic study of the otoliths of the neopterygean marine fishes of South. Africa. Part I Introduction. Trans. R. Soc. S. Afr. 43: 191-197

Hourigan, T. F., Radtke, R. L. (1989). Reproduction of the Antarctic fish Nototheniops nudifrons. Mar. Biol. 100: 277-283

Iwami, T., Abe, T (1982). Notes on the fishes collected during the 1980-1981 exploratory bottom trawl fishing off the South Shetland Islands. In: Hoshai, T. Naito, Y (eds.) Proc 5th Symp. on Antarctic Biology., Mem. Nat Inst. Pol. Res., Spec. Iss. 23: 55-63

Jones, C. (1986). Determining age of Larval fish with the otolith increment technique. Fish. Bull. U. S. 84: 91-103

Kellermann, A. (1986a). On the biology of early life stages of notothenioid fishes (Pisces) off the Antarctic Peninsula. Ber Polarforsch. 31: $149 \mathrm{pp}$

Kellermann, A. (1986b) Geographical distribution and abundance of postlarval and juvenile Pleuragramma antarcticum (Pisces, Notothenioidei) off the Antarctic Peninsula. Polar Biol. 6: 111-119

Kock, K. H. (1982). Fischereibiologische Untersuchungen bei Elephant. Island im Marz 1981. Arch. FischWiss. 33 (1) $127=142$

Kock, K. H., Duhamel G., Hureau, J. C. (1985). Biology and status of exploited Antarctic fish stock: a review. BIOMASS Scient. Ser. 6: 1-143 
Methot, R. D., Jr., Kramer, D. (1979). Growth of northern anchovy, Engraulis mordax, larvae in the sea. Fish. Bull. U. S. 77: 413-423

Morrow, J. E. (1979). Preliminary keys to otoliths of some adult fishes of the Gulf of Alaska, Bering Sea and Beaufort Sea. NOAA Tech. Rep. NMFC Cir 420, p. $1-32$

North, A. W., Burchett, M. S., Gilbert, C. J., White, M. G. (1984). Identification of fish from the Southern Ocean by means of otoliths. Br. Antarct. Surv. Bull. 62: 83-94

North, A. W., White, M. G., Burchett, M. S. (1980). Age determination of Antarctic fish. Cybium 3e serie 8: 7-11

Nybelin, O. (1947). Fishes collected during the NorvegianBritish Antarctic Expedition 1949-52. Göteborgs Kungl. Net. Vitterh. Samhäll. Hand Ser. B. 6 (7): 1-13

Olsen, S. (1955). A contribution to the systematics and biology of Chaenichthyid fishes from South Georgia. Nytt. Mag. Zool. Oslo 3: 79-93

Pannella, G. (1971). Fish otoliths: daily growth layers and periodical patterns. Science 173: 1124-1127

Pannella, G. (1974). Otolith growth patterns: an aid in age determination in temperate and tropical fishes. In: Bagenal, T B. (ed.) The ageing of fish. Unwin Brothers, Ltd, Old Woking, p. 28-39

Pannella, G. (1980). Growth patterns in fish sagittae. In: Rhoads, D. C., Lutz, R. A., (eds.) Skeletal growth of aquatic organisms: biological records of environmental change. Plenum Press. New York, p. 519-560

Permitin, Yu. Ye. (1977). Species composition and zoogeographical analysis of the bottom fish fauna of the Scotia Sea. J. Ichthyol. 17 (5): 710-726

Radtke, R. L. (“984). Cod fish otoliths: information storage structures. Flødevigen rapportser. 1: 273-298

Radtke, R. L., Waiwood, K. G. (1980). Otolith formation and body shrinkage due to fixation in larval cod (Gadus morhua). Can. Tech. Rep. Fish. Aquat. Sci. 929: iii + $10 \mathrm{p}$

This article was presented by Dr K. Sherman, Narragansett, Rhode Island, USA
Radtke, R. L., Dean, J. M. (1982). Increment formation in the otoliths of embryos, larvae, and juveniles of the mummichog, Fundulus heteroclitus. Fish. Bull. U. S. 80: 201-215

Radtke, R. L., Hourigan, T F. (1989). Age and growth of the Antarctic fish Nototheniops nudifrons. Fish. Bull. U. S. (in press)

Radtke, R. L., Targett, T E. (1984). Rhythmic structural and chemical patterns in otoliths of the Antarctic fish Notothenia larseni: their application to age determination. Polar Biol. 3: 203-210

Richardson, M. G. (1975). The dietary composition of some Antarctic fish. Br. Antarct. Sur. Bull 41: 113-120

Ricker, W. E. (1973). Linear regressions in fishery research. J. Fish. Res. Bd Can. 30: 409-434

Ricker, W. E. (1975). Computation and interpretation of biological statistics of fish populations. Bull. Fish. Res. Bd Can. 191: 1-382

Shust, K. V., Pinskaya, I. A. (1978). Age and rate of growth of six species of notothenid fish (family Nototheniidae). J. Ichthyol. 18 (5): 743-749

Six, L. D., Horton, H. F. (1977). Analysis of age determination methods for yellowtail rockfish, canary rockfisch, and black rockfish off Oregon. Fish. Bull U. S. 75: 405-414

Tanaka, K., Mugiya, Y., Yamada, J. (1981). Effects of photoperiod and feeding on daily growth patterns in otoliths of juvenile Tilapia nilotica. Fish. Bull. U. S. 79: 459-466

Targett, T. E. (1981). Trophic ecology and structure of coastal Antarctic fish communities. Mar. Ecol. Prog. Ser. 4: 243-263

Townsend, D. W. (1980). Microstructural growth increments in some Antarctic fish otoliths. Cybium 3e serie 8: 17-22

Weber, D. D., Ridgeway, G. J. (1967). Marking Pacific salmon with tetracyline antibiotics. J. Fish. Res. Bd Can. 24: 849-865

Manuscript first received: April 8, 1988

Revised version accepted: June 22, 1989 